\title{
Propolis supplementation affects performance, intestinal morphology, and bacterial population of broiler chickens
}

\author{
S. Sadarman ${ }^{1,9}$, E. Erwan1, A. Irawan ${ }^{2,9}$, M.M. Sholikin ${ }^{3,9}$, R. Solfaine ${ }^{4}$, R.P. Harahap ${ }^{5,9}$, A.C.

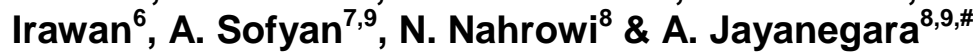 \\ ${ }^{1}$ Department of Animal Science, Sultan Syarif Kasim State Islamic University, Pekanbaru 28293, Indonesia \\ ${ }^{2}$ Vocational Program of Animal Husbandry, Universitas Sebelas Maret, Surakarta 57126, Indonesia \\ ${ }^{3}$ Graduate School of Nutrition and Feed Science, Faculty of Animal Science, IPB University, Bogor 16680, Indonesia \\ ${ }^{4}$ Department of Pathology, Faculty of Veterinary Medicine, Universitas Wijaya Kusuma, Surabaya 60225, Indonesia \\ ${ }^{5}$ Animal Science Study Program, Faculty of Agriculture, Tanjungpura University, Pontianak 78124, Indonesia \\ ${ }^{6}$ Animal Science Study Program, Faculty of Agriculture, Kediri Islamic University, Kediri 64128, Indonesia \\ ${ }^{7}$ Research Division for Natural Product Technology, Indonesian Institute of Sciences, Yogyakarta 55861, Indonesia \\ ${ }^{8}$ Department of Nutrition and Feed Technology, Faculty of Animal Science, IPB University, Bogor 16680, Indonesia \\ ${ }^{9}$ Animal Feed and Nutrition Modelling (AFENUE) Research Group, Department of Nutrition and Feed Technology, \\ Faculty of Animal Science, IPB University, Bogor 16680, Indonesia
}

(Received 14 February 2021; Accepted 13 June 2021; Published 13 August 2021)

Copyright resides with the authors in terms of the Creative Commons Attribution 4.0 South African Licence.
See: http://creativecommons.org/licenses/by/4.0/za
Condition of use: The user may copy, distribute, transmit and adapt the work, but must recognise the authors and the South African
Journal of Animal Science.

\begin{abstract}
A meta-analysis was conducted to examine the effect of supplementing the diet of broiler chickens with propolis on growth, bacterial population of the intestine, antiviral serum concentration, intestinal morphology, and digestive enzyme activities in broiler chickens. Forty peer-reviewed articles that had been published between 2003 and 2019 were identified using the PRISMA protocol and included in the study. Data were analysed with mixed model methodology, in which the studies were considered random effects, whereas the level of supplemental propolis was considered a fixed effect. Responses to propolis supplementation in bodyweight (BW) and average daily gain (ADG) were quadratic, but average daily feed intake (ADFI) was not affected. Propolis supplementation improved feed conversion ratio (FCR) significantly as a linear function of the level of supplement. The optimum level of supplementation was between 256 and $262 \mathrm{mg} / \mathrm{kg}$ feed and produced maximum ADG and final BW. There was a tendency for mortality to decrease because of propolis supplementation. Propolis had no detectable effect on serum antiviral concentration, intestinal bacterial population or intestinal morphology. Among digestive enzymes, only sucrase increased linearly as propolis was increased. Thus, supplementation with propolis increased the growth performance of broiler chickens positively and the effect was dose dependent. This may have been partly because of an improvement in sucrase activity and other factors related to the nutritional content of propolis. Future study to evaluate specific bioactive compounds of propolis is therefore warranted.
\end{abstract}

Keywords: bee glue, digestive enzymes, growth, meta-analysis

\#Corresponding author: anuraga.jayanegara@gmail.com

\section{Introduction}

Successful broiler production is determined largely by rearing management, including disease prevention and proper use of medication. Antibiotics are commonly used as therapeutic agents to control diseases, and used to be a popular growth-promoting feed additive (AGP). Antibiotic metabolites, which can inhibit the growth of microorganisms in low doses, are produced by fungi and algae and are manufactured chemically (Nir \& Ve-Senkoylu, 2000). Their use as AGPs was aimed at improving feed efficiency, but raised problems because bacteria acquired resistance to antibiotics from uncontrolled use (Bronzwaer et al., 2002; FAO \& IFIF, 2010; Attia et al., 2019a, b). Thus, the use of antibiotics as AGPs is no longer allowed worldwide. Consequently, there has been growing interest in replacing AGPs with natural products that are readily available and safe for poultry, including spices, herbs, plant extracts, antioxidants, enzymes, probiotics, and prebiotics (Khattak et al., 2006; Toghyani et al., 2011; Abdel-Kareem \& El-Sheikh, 2015; 
Omar et al., 2016; Cimrin et al., 2020; Attia et al., 2016). Among these natural resources, propolis has shown potential as an AGP (Attia et al., 2014; Abou-Zeid et al., 2015; Klarić et al., 2018).

Propolis or 'bee glue' is a resinous substance that is collected by honeybees from flowers and shoots of trees such as willow, poplar and wild chestnut. Its bioactive components consist of polyphenols, phenol aldehydes, aromatic compounds, steroids, fatty acids, enzymes, essential minerals and vitamins, tevels of which vary according to plant species, location and time of collection (Lotfy, 2006; Krocko et al., 2012; Klarić et al., 2018). In practice, propolis has been used among others as an antioxidant, antimicrobial, antiinflammatory, antiradiation, and hepatoprotective substance in animals and humans (Bankova, 2005; Yamaguchi et al., 2006; Pascoal et al., 2014). Studies reported effective use of propolis as a therapeutic agent against many human diseases, including heart disease, cancer, diabetes mellitus and inflammation (Mishima et al., 2005). In several animal species, propolis has been reported to promote animal growth, improve the quality and safety of animal products, increase immune response, and regulate the intestinal tract (Liu et al., 2010). In broiler chickens, propolis reportedly enhanced performance and health status (Attia et al., 2014; Abou-Zeid et al., 2015; Rabie et al., 2018). In rabbits, propolis was effective in replacing zinc bacitracin (antibiotic) with positive improvements in growth performance, economic benefit, immune status, and reproduction (Attia et al., 2015, 2019a, 2019b).

The beneficial effects of propolis on growth performance can be explained by several mechanisms. Klarić et al. (2018) revealed a positive effect on the health status of chickens as shown by haematological parameters when they consumed a diet supplemented with propolis. Its efficacy as an immunomodulator was demonstrated by improvement in blood globulin levels and a positive response in humoral immunity (Hassan et al., 2018; Attia et al., 2016). In addition, propolis and bee pollen had beneficial effects on intestinal morphology, increasing the surface area for nutrient absorption in broilers (Chegini et al., 2018; Prakatur et al., 2019; Attia et al., 2019a, b). Therefore propolis was suggested as an effective alternative additive for use in intensive animal production (Attia et al., 2019a).

Although a number of studies have discussed the effects of propolis on broiler production, none has attempted to summarize the findings and to provide robust conclusions for propolis use. The present study therefore aimed to evaluate the effects of dietary propolis supplementation on growth performance, bacterial count in the intestinal tract, immune response, morphology of the small intestine, and activity of digestive enzymes in broilers. The study was performed using data from the literature and employing a meta-analysis approach based on a mixed-model methodology to analyse them quantitatively.

\section{Materials and Methods}

A systematic literature search following the PRISMA (Preferred Reporting Items for Systematic Reviews and Meta-Analysis) protocol (Page et al., 2021) was conducted to identify studies reporting immune and enzymatic responses and intestinal morphology of broiler chickens fed a diet containing propolis. A combination of search terms that included 'propolis', 'broiler', 'bacterial population', and 'intestinal morphology', was applied to databases of Science Direct (2021), PubMed (2021), and Scopus (2021). Only articles published in international peer-reviewed journals were retained in the screening process. A total of 75 articles were identified from title and abstract evaluation. These were further screened on a full-text basis according to pre-determined criteria, namely i) the article must report the use of propolis in the diet; ii) the form of propolis should be explained, that is, whether crude or extracted; iii) inclusion level must be reported; and iv) the effects on growth performance, number of bacteria, immune response, and antioxidant activity must be recorded. A total of 39 articles met these criteria (Table 1).

The database contained the authors and year of publication, strain of broiler chicken, sex, form of propolis, rearing phase (starter or finisher), levels of propolis inclusion, and response variables reported in the articles, which included BW, ADG, daily feed intake, FCR ratio, mortality, intestinal bacteria population (Bacteroidaceae, Bifidobacterium spp., Clostridiaceae), anti-viral response (anti-Newcastle disease serum titer), intestinal morphology (height and width of villi in the duodenum, jejunum and ileum), and activity of the digestive enzymes sucrase, maltase, amylase, chymotrypsin, lipase and trypsin. 
Table 1 Literature that provided data for a meta-analysis on the effects of propolis ( $\mathrm{mg} / \mathrm{kg}$ of feed) on broilers

\begin{tabular}{|c|c|c|c|c|c|c|}
\hline \multirow{2}{*}{ Reference } & \multirow{2}{*}{ Level, mg/kg diet } & \multirow{2}{*}{ Broiler strain } & \multirow{2}{*}{ Sex } & \multicolumn{3}{|c|}{ Rearing period, $\mathrm{d}$} \\
\hline & & & & Starter & Finisher & Total \\
\hline Biavatti et al., 2003 & $0-570$ & Ross 308 & Male & $1-21$ & $22-28$ & $1-28$ \\
\hline Açıkgöz et al., 2005 & $0-2000$ & Ross 308 & Male & $1-28$ & $29-42$ & $1-42$ \\
\hline Taheri et al., 2005 & $0-1000$ & Ross 308 & Mixed & $1-21$ & $22-42$ & $1-42$ \\
\hline Ziaran et al., 2005 & $0-1000$ & Ross 308 & - & $1-21$ & $22-47$ & $1-47$ \\
\hline Shalmany \& Shivazad, 2006 & $0-250$ & Ross 308 & - & $1-21$ & $22-42$ & $1-42$ \\
\hline Seven \& Seven, 2008 & $0-1500$ & Ross 308 & Male & $1-21$ & $22-42$ & $1-42$ \\
\hline Seven et al., 2008 & $0-5000$ & Ross 308 & - & - & - & $1-42$ \\
\hline Seven et al., 2008 & $0-3000$ & Ross 308 & Mixed & $3-21$ & $22-41$ & $3-41$ \\
\hline Khodanazary et al., 2011 & $0-1000$ & Ross 308 & - & $1-21$ & $22-42$ & $1-42$ \\
\hline Tekeli et al., 2011 & $0-3000$ & Ross 308 & - & - & - & $8-42$ \\
\hline Daneshmand et al., 2012 & $0-200$ & Ross 308 & Male & $1-21$ & $22-42$ & $1-42$ \\
\hline Seven et al., 2012 & $0-1000$ & Ross 308 & - & $3-21$ & $22-41$ & $3-41$ \\
\hline Eyng et al., 2013 & $0-500$ & Cobb 500 & Male & $1-21$ & - & - \\
\hline Mahmoud et al., 2013 & $0-750$ & Ross 308 & Male & $1-21$ & $22-42$ & $1-42$ \\
\hline Abbas, 2014 & $0-2500$ & Ross 308 & Male & - & - & $1-28$ \\
\hline Attia et al., 2014 & $0-300$ & Arbor Acres & Mixed & $1-21$ & $22-35$ & $1-35$ \\
\hline Duarte et al., 2014 & $0-500$ & Cobb 500 & Male & $1-21$ & - & $1-42$ \\
\hline Eyng et al., 2014 & $0-5000$ & Cobb 500 & Male & $1-21$ & - & $1-42$ \\
\hline Abou-Zeid et al., 2015 & $0-500$ & Cobb 500 & Mixed & - & - & $1-42$ \\
\hline Daneshmand et al., 2015 & $0-200$ & Ross 308 & Male & $1-21$ & $22-42$ & $1-42$ \\
\hline Eyng et al., 2015 & $0-4000$ & Cobb 500 & Male & - & - & $1-21$ \\
\hline Torki et al., 2015 & $0-200$ & Ross 308 & - & $1-21$ & $22-42$ & $1-42$ \\
\hline Haščík et al., 2016 & $0-400$ & Ross 308 & Mixed & $1-21$ & $22-42$ & $1-42$ \\
\hline Hosseini et al., 2016 & $0-3000$ & Ross 308 & Male & $1-21$ & $22-42$ & $1-42$ \\
\hline Eyng et al., 2017 & $0-5000$ & Cobb 500 & Male & $1-21$ & - & $1-21$ \\
\hline Gheisari et al., 2017 & $0-300$ & Ross 308 & Male & $1-21$ & $22-42$ & $1-42$ \\
\hline Mahmoud et al., 2017 & $0-3000$ & Ross 708 & Male & - & - & $1-42$ \\
\hline Sahin \& Ozturk, 2017 & $0-400$ & Ross 308 & Female & - & - & $16-20$ \\
\hline Shaddel-Tili et al., 2017 & $0-2000$ & Ross 308 & Male & $1-24$ & $25-42$ & $1-42$ \\
\hline Chegini et al., 2018 & $0-5000$ & Ross 308 & Male & $1--21$ & $22--42$ & $1-42$ \\
\hline Kinasih et al., 2018 & $0-1000$ & Ross 308 & Mixed & $1--21$ & $22--42$ & $1-42$ \\
\hline Klarić et al., 2018 & $0-1000$ & Cobb 500 & - & $1--21$ & $22--42$ & $1-42$ \\
\hline Rabie et al., 2018 & $0-500$ & Iraqi rooster & Male & - & - & - \\
\hline Hassan et al., 2018 & $0-400$ & Ross 308 & Mixed & $1-21$ & $22-42$ & $1-42$ \\
\hline Al-Sultan et al., 2019 & $0-3000$ & Ross 308 & - & $1-21$ & $22-42$ & $1-42$ \\
\hline Abdelsalam et al., 2019 & $0-400$ & Cobb 500 & Mixed & $1-21$ & $22-49$ & $1-49$ \\
\hline Alani et al., 2019 & $0-800$ & Cobb 500 & Mixed & - & - & - \\
\hline Haščík et al., 2019 & $0-1000$ & Ross 308 & Mixed & $1-21$ & $22-42$ & $1-42$ \\
\hline Khafaji et al., 2019 & $0-000$ & Ross 308 & Mixed & $1-21$ & $22-42$ & $1-42$ \\
\hline
\end{tabular}

Statistical analysis was conducted using a mixed-model methodology following the examples of StPierre (2001) and Sauvant et al. (2008), in which the studies were considered random effects and the level of propolis inclusion was a fixed effect. The mathematical models used in this study were as follows: 


$$
\begin{gathered}
Y_{i j}=\beta_{0}+\beta_{1} \text { Level }_{i j}+\text { Experiment }_{i}+\text { Experiment }_{i} \text { Level }_{i j}+e_{i j} \\
Y_{i j}=\beta_{0}+\beta_{1} \text { Level }_{i j}+\beta_{2} \text { Level }_{i j}^{2}+\text { Experiment }_{i}+\text { Experiment }_{i} \text { Level }_{i j}+e_{i j}
\end{gathered}
$$

These models differ only by the inclusion of a quadratic effect of level in the second model. In these models, $Y_{i j}$ is the dependent variable, $\beta_{0}$ is the intercept, $\beta_{1}$ and $\beta_{2}$ are linear and quadratic regression coefficients, Level $_{i j}$ is level of propolis used to produce the observed response in Experiment ${ }_{i}$, and $e_{i j}$ is random residual error. Statistics that were used to establish the importance of effects included in the models were the $P$-value, root mean square error (RMSE), and Akaike information criterion (AIC). Effects were considered significant when $P \leq 0.05$, and tendency was thought to exist when $0.05<P \leq 0.10$. Initially, the quadratic model was applied. When $P>0.10$ was observed for the quadratic effect of level, then the corresponding linear model was applied. Data were analysed using R software version 3.6.3 within the 'nlme' library (Pinheiro et al., 2020; R Core Team, 2020).

\section{Results and Discussion}

Propolis contains more than 300 compounds, which make its composition complex (Sahin \& Ozturk, 2018). Geographical differences, climatic characteristics, bee genetics, and seasons also affect its composition, making it difficult to determine which compounds affect responses to it use as a dietary supplement. The average composition of crude propolis is approximately $50 \%$ resin and balsam, $30 \%$ wax, $10 \%$ essential and aromatic oils, $5 \%$ pollen, and $5 \%$ impurities (Marcucci, 1995). To the authors' knowledge, no studies on the effects of specific bioactive compounds of propolis have been reported for broiler chickens.

Bodyweight and ADG exhibited quadratic responses to the level of propolis supplementation ( $P$ $<0.01$ ). Bodyweight had a predicted maximum value of $2186 \mathrm{~g}$ when propolis was supplemented at 262 $\mathrm{mg} / \mathrm{kg}$. Likewise, a maximum ADG of $60.8 \mathrm{~g} / \mathrm{d}$ was obtained when propolis was included at $256 \mathrm{mg} / \mathrm{kg}$. Inclusion of propolis in the diet did not affect daily feed intake significantly. However, it decreased FCR linearly. In addition, there was a tendency for linear decrease in mortality owing to an increase in the level of propolis supplementation. The effects of propolis supplementation on the growth performance of broiler chickens are presented in Table 2.

Table 2 Regression equations describing effects of dietary propolis ( $\mathrm{mg} / \mathrm{kg}$ feed) on the performance of broilers

\begin{tabular}{lrrrrrrrr}
\hline $\begin{array}{l}\text { Response } \\
\text { variable }\end{array}$ & $\mathrm{N}$ & \multicolumn{3}{c}{ Parameter estimates } & \multicolumn{2}{c}{$P$-value } & RMSE & AIC \\
\cline { 3 - 7 } & & \multicolumn{1}{c}{ Intercept } & \multicolumn{1}{c}{ Linear } & Quadratic & Linear & Quadratic & \\
\hline BW, g & 130 & $2072 \pm 101$ & $870 \pm 253$ & $1.658 \pm 0.5930$ & 0.001 & 0.006 & 2.13 & 1730 \\
ADG, g/d & 130 & $57.6 \pm 4.46$ & $25.0 \pm 7.20$ & $-0.0489 \pm 0.0167$ & 0.001 & 0.004 & 1.97 & 836 \\
DFI, g/d & 126 & $122 \pm 17.70$ & $4.35 \pm 3.93$ & & 0.271 & & 2.24 & 958 \\
FCR & 126 & $1.99 \pm 0.09$ & $-0.538 \pm 0.259$ & & 0.040 & & 1.98 & 677 \\
Mortality, \% & 27 & $5.96 \pm 1.70$ & $-9.20 \pm 4.68$ & & 0.065 & & 1.28 & 145
\end{tabular}

BW: bodyweight, ADG: average daily gain, AIC: Akaike information criterion, DFI: daily feed intake, FCR: feed conversion ratio, $\mathrm{N}$ : number of observations, RMSE: root mean square error

The meta-analysis confirmed the results of numerous individual studies that reported promising effects of propolis supplementation on the performance of animals (Attia et al., 2014; 2016; 2019a,b). For instance, Rabie et al. (2018) reported that broilers fed diets containing propolis (400 mg/kg diet) had higher BW as a result of higher ADG. Similarly, Attia et al. (2014) reported that supplementation of $300 \mathrm{mg} / \mathrm{kg}$ propolis to broiler diets increased BW significantly by $12 \%$. Results from other studies in which propolis at various levels of inclusion and in either crude or extracted forms showed increased BW gain of broilers (Seven, 2008; Seven et al., 2008; Klarić et al., 2018; Hassan et al., 2018). The current study showed little effect of propolis 
on bacterial population in the digestive tract of broiler chickens, although other studies revealed positive modulation effects of propolis on gut microbiota (Klarić, 2014; Eyng et al., 2017). The results of the current study are supported by the finding that the addition of ethanolic extract of propolis at various levels in broiler chicken feed did not affect intestinal microbiota (Eyng et al., 2017). Propolis possibly promoted growth performance in broilers because of the increase of certain enzyme activities, primarily sucrase, as shown in this study. Other plausible reasons are related to the nutritional and bioactive contents of propolis, such as vitamins, flavonoids, minerals, and essential oils (Figure 1) (Awadalla \& Kamel, 2000; Gardana et al., 2007; Easton-Calabria et al., 2019).

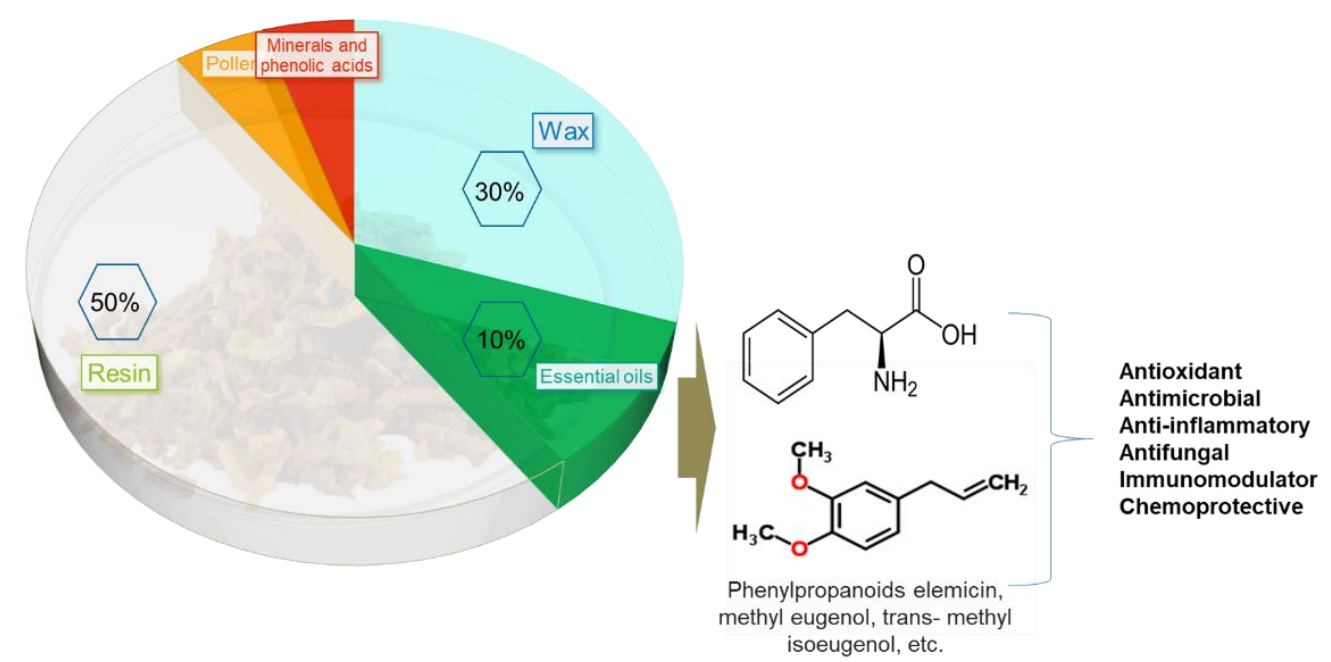

Figure 1 Raw propolis composition and its main functions (adapted from Easton-Calabria et al., 2019) transmethyl

Propolis had no effect on some species of intestinal bacteria population, although this has to be interpreted cautiously because of limited data (Table 3$)$. There was no effect $(P>0.05)$ on Newcastle disease antibody titer.

Table 3 Linear regression analysis of the size of intestinal bacteria populations and Newcastle disease antibody titers on the level of propolis supplementation in the diet $(\mathrm{mg} / \mathrm{kg}$ feed)

\begin{tabular}{lcccccc}
\hline Response variable & $\mathrm{N}$ & Intercept & Slope & $P$-value & RMSE & AIC \\
\hline Bacterial composition & & & & & & \\
$\quad$ Bacteroidaceae, $\log _{10} \mathrm{cfu} / \mathrm{g}$ & 12 & $4.36 \pm 0.33$ & $0.195 \pm 1.51$ & 0.900 & 1.22 & 36.4 \\
$\quad$ Clostridiaceae, $\log _{10} \mathrm{cfu} / \mathrm{g}$ & 12 & $4.51 \pm 0.67$ & $-3.63 \pm 3.12$ & 0.274 & 1.25 & 53.8 \\
$\quad$ Enterobacteriaceae, $\log _{10} \mathrm{cfu} / \mathrm{g}$ & 18 & $3.64 \pm 1.15$ & $-0.178 \pm 1.34$ & 0.896 & 1.30 & 54.1 \\
Newcastle disease antibody titers & & & & & & \\
$\quad$ Starter phase & 20 & $1547 \pm 426$ & $-2816 \pm 2194$ & 0.218 & 1.13 & 303 \\
$\quad$ Finisher phase & 33 & $1258 \pm 293$ & $-925 \pm 935$ & 0.331 & 1.33 & 513 \\
& & & & & & \\
\hline
\end{tabular}

AIC: Akaike information criterion, $\mathrm{N}$ : number of observations, RMSE: root mean square error

The addition of propolis did not affect $(P>0.05)$ villus height, crypt depth of the duodenum or the ratio of villus height to crypt depth in the duodenum, jejunum, and ileum. There were significant linear increases $(P<0.05)$ of the sucrase enzyme in the duodenum and jejunum. However, amylase, chymotrypsin, maltase 
and trypsin were not influenced $(P>0.05)$. Table 4 presents the intestinal morphology and enzyme activity of broiler chickens as influenced by levels of propolis.

Table 4 Linear regression analysis of intestinal morphology and enzyme activity of broilers on the level of propolis supplementation in the diet $(\mathrm{mg} / \mathrm{kg}$ feed)

\begin{tabular}{|c|c|c|c|c|c|c|}
\hline Response variable & $\mathrm{N}$ & Intercept & Slope & $P$-value & RMSE & AIC \\
\hline \multicolumn{7}{|l|}{ Duodenum } \\
\hline Villus height, $\mu \mathrm{m}$ & 25 & $1,609 \pm 251$ & $-45.6 \pm 148.5$ & 0.762 & 1.3 & 324 \\
\hline Crypt depth, $\mu \mathrm{m}$ & 25 & $206 \pm 54$ & $21.8 \pm 26.0$ & 0.412 & 1.43 & 239 \\
\hline $\mathrm{VH} / \mathrm{CD}$ & 25 & $8.89 \pm 1.03$ & $-0.494 \pm 2.12$ & 0.818 & 1.5 & 100 \\
\hline Sucrase, U/mg & 12 & $4.07 \pm 0.48$ & $8.64 \pm 2.24$ & 0.004 & 1.33 & 45.9 \\
\hline Maltase, Ul/mg & 12 & $24.4 \pm 1.81$ & $13.4 \pm 8.41$ & 0.146 & 1.14 & 77.6 \\
\hline \multicolumn{7}{|l|}{ Jejunum } \\
\hline Villus height, $\mu \mathrm{m}$ & 21 & $901 \pm 86$ & $-53.8 \pm 85.1$ & 0.536 & 1.2 & 249 \\
\hline Crypt depth, $\mu \mathrm{m}$ & 21 & $159 \pm 19$ & $-10.1 \pm 9.7$ & 0.313 & 1.13 & 163 \\
\hline $\mathrm{VH} / \mathrm{CD}$ & 21 & $5.9 \pm 0.65$ & $-0.106 \pm 0.45$ & 0.813 & 1.41 & 31.0 \\
\hline Sucrase, UI/mg & 12 & $5.26 \pm 0.85$ & $10.4 \pm 3.80$ & 0.023 & 1.04 & 57.9 \\
\hline Maltase, Ul/mg & 12 & $27.1 \pm 1.92$ & $10.5 \pm 8.93$ & 0.269 & 1.08 & 79.0 \\
\hline \multicolumn{7}{|l|}{ Ileum } \\
\hline Villus height, $\mu \mathrm{m}$ & 15 & $638 \pm 89$ & $52.9 \pm 60.8$ & 0.403 & 1 & 165 \\
\hline Crypt depth, $\mu \mathrm{m}$ & 15 & $126 \pm 16$ & $10.2 \pm 14.6$ & 0.498 & 1.06 & 120 \\
\hline $\mathrm{VH} / \mathrm{CD}$ & 15 & $5.09 \pm 0.20$ & $0.04 \pm 0.35$ & 0.918 & 1.22 & 4.47 \\
\hline Sucrase, UI/mg & 12 & $6.3 \pm 0.66$ & $2.77 \pm 1.85$ & 0.168 & 1.19 & 39.1 \\
\hline Maltase, UI/mg & 12 & $31.1 \pm 2.75$ & $1.98 \pm 9.79$ & 0.844 & 1.16 & 79 \\
\hline Amylase, $\mathrm{nmol} / \mathrm{mg}$ & 12 & $4.55 \pm 0.44$ & $-0.146 \pm 2.02$ & 0.944 & 1.19 & 43.4 \\
\hline Chymotrypsin, nmol/mg & 12 & $4.86 \pm 0.27$ & $-0.703 \pm 1.25$ & 0.587 & 1.34 & 31.9 \\
\hline Lipase, UI/mg & 12 & $16.5 \pm 3.15$ & $0.71 \pm 7.69$ & 0.928 & 1.08 & 73.5 \\
\hline Trypsin, nmol/mg & 12 & $26.3 \pm 6.35$ & $-1.28 \pm 10.5$ & 0.906 & 1.12 & 82.3 \\
\hline
\end{tabular}

AIC: Akaike information criterion, N: number of observations, RMSE: Root mean square error; VH/CD: ratio of villus height to crypt depth

The present meta-analysis failed to show an effect of propolis supplementation on the immune function of broilers, possibly because studies that evaluate the immune-modulatory effects of propolis on broiler chickens are few, with large variation among them making it difficult to generalize. A number of studies reported a positive effect in increasing immunoglobulins $\lg A$, $\lg M$, and $\lg Y$ (Seven et al., 2010), and on the formation of the viral antibody (Seven et al., 2012; Eyng et al., 2013a; Eyng et al., 2013b), but they should be interpreted cautiously. The present study also failed to provide evidence on the modulating effect of propolis on intestinal bacterial population. Eyng et al. (2015) reported increases in macrophage phagocytes and in red blood cells in broilers that received a diet containing $500 \mathrm{mg} / \mathrm{kg}$ propolis, which indicated that propolis increased cellular response through macrophage cell activation pathways. This was effective in increasing the immune response of broilers and could increase the number of monocytes, but had no effect on the number of basophil cells or nitric oxide enzymes (Khan, 2017). In addition, propolis inclusion could reduce significantly the number of heterophile cells and lymphocytes in broilers that are 
induced by phytohemagglutinin, which indicated that propolis inhibited tissue damage from pathogens and viruses by increasing white blood cells (Abdelsalam et al., 2019).

Propolis could play a role in counteracting free radicals by increasing the activity of superoxide dismutase, catalase and glutathione peroxidase and significantly reducing the activity of malondialdehyde. This mechanism indicated that propolis exhibited immunomodulation and inhibition of tissue damage caused by free radicals by activating antioxidant enzymes in broiler chickens (Abou-Zeid et al., 2015). An interconnected factor could explain the beneficial effects of propolis on immune response and intestinal characteristics and ecology (Figure 2). Propolis improved productive and reproductive performance in rabbits, as shown by higher litter size, survival, and growth rates of kits (Attia et al., 2015, 2019a). A subsequent study indicated that supplementation with propolis produced increased white blood cell and lymphocyte counts, greater phagocytic activity, and increased levels of serum $\beta$-globulin, indicative of higher antibody response (Attia et al., 2019b). Many authors reported positive effects on intestinal morphology (Eyng et al., 2016; Klarić et al., 2018; Prakatur et al., 2019) and on immune response and enzyme activity (Wang et al., 2007; Abdel-Mohsein et al., 2014; Attia et al., 2019b). However, no positive effects on the morphology of broiler small intestines were observed in the present study, which provided further evidence of inconsistent responses to propolis supplementation. This variability in response to propolis supplementation might be influenced by its complex composition

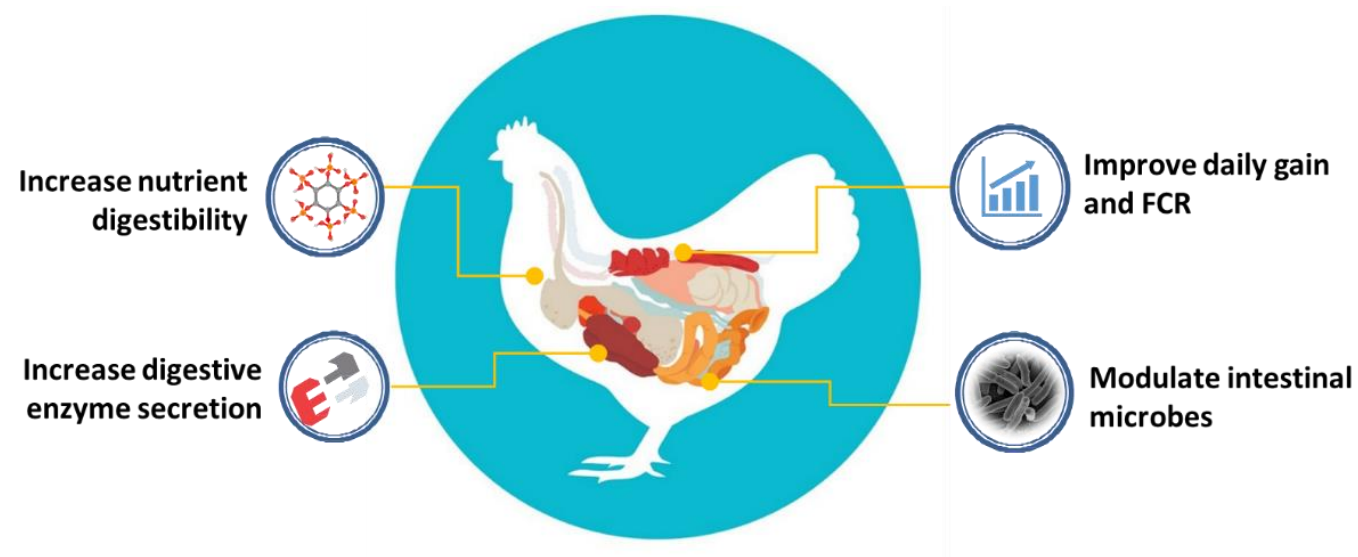

Figure 2 Mode of action of propolis as growth-promoting additive in broiler chickens

There is a correlation between intestinal microbiota and morphology (Hanhineva et al., 2010; AbdelMohsein et al., 2014). Active compounds of propolis can produce aromatic metabolites when metabolized by intestinal bacteria, which may interact with bacterial cells and inhibit their growth (Biavatti et al., 2003; Açıkgöz et al., 2005). Consequently, intestinal morphology may be improved, and this may promote enzyme production and nutrient absorption (Abdel-Mohsein et al., 2014; Prakatur et al., 2019). Interestingly, in the present study an increase was observed in sucrase activity, particularly in the duodenum and jejunum. Phenolic compounds of propolis could contribute to glucose metabolism because they were reported to stimulate insulin secretion (Taheri et al., 2005; Shalmany \& Shivazad, 2006).

\section{Conclusion}

Propolis supplementation has an apparent dose-dependent growth-promoting effect on broiler chickens. Its addition to the diet at $256-262 \mathrm{mg} / \mathrm{kg}$ was predicted to produce maximum ADG and final BW. However, it affected only the digestive enzyme sucrase, which increased linearly with the amount provided. Further study would be indicated to investigate how the specific components of propolis affect the performance and health of broiler chickens

\section{Authors' Contributions}

$\mathrm{S}$, EW, Al, and RS conceptualized the research design and conducted the literature selection. MMS, RPS, and $\mathrm{ACl}$ performed database development and formal analysis. S and Al wrote the original draft of manuscript, $\mathrm{AS}, \mathrm{N}$, and AJ checked the database, supervised the research, and revised the manuscript.

\section{Conflict of Interest Declaration}

All authors declare that there are no conflicts of interest 


\section{References}

Abbas, R.J., 2014. Effect of dietary supplementation with differing levels of propolis on productivity and blood parameters in broiler chicks. Basrah J. Vet. Res. 13, 164-179.

Abdel-Kareem, A.A.A. \& El-Sheikh, T.M., 2015. Impact of supplementing diets with propolis on productive performance, egg quality traits and some haematological variables of laying hens. J. Anim. Physiol. Anim. Nutr. 101(3), 441448. https://doi.org/10.1111/jpn.12407

Abdel-Mohsein, H.S., Mahmoud, M.A.M. \& Mahmoud, U.T., 2014. Influence of propolis on intestinal microflora of Ross broilers exposed to hot environment. Advances in Animal and Veterinary Sciences 2(4), 204-211.

Abdelsalam, A.M., Abd-Elazim, A.M., Othman, A.M.R., Makram, A. \& Omar, E.M., 2019. Blood hematological and biochemical parameters and humoral immunity as affected by added dietary propolis supplementation of Cobb broiler chicks. Egypt J. Nutr. Feeds. 22(2), 215-221.

Abdollahi, M.R., Duangnumsawang, Y., Kwakkel, R.P., Steenfeldt, S., Bootwalla, S.M. \& Ravindran, V., 2016. Investigation of the interaction between separate calcium feeding and phytase supplementation on growth performance, calcium intake, nutrient digestibility and energy utilisation in broiler starters. Anim. Feed Sci. Technol. 219, 48-58. https://doi.org/10.1016/j.anifeedsci.2016.05.017

Abou-Zeid, A.E., El-Damarawy, S.Z., Mariey, Y.A. \& El-Kasass, S.M., 2015. Effect of dietary propolis supplementation on performance and activity of antioxidant enzymes in broiler chickens. Egypt J. Nutr. Feeds. 18, 391-400.

Açikgöz, Z.Z., Yücel, B. \& Altan, Ö., 2005. The effects of propolis supplementation on broiler performance and feed digestibility. Archiv fur Geflugelkunde 69 (3), 117-122.

Alani, A.A.T., Alheeti, A.S.A. \& Alani, E.N.S., 2019. Comparison between effect of adding propolis and antibiotic in in broiler chickens on productive performance and carcass traits. IOP Conference Series. Earth Environ. Sci. 388 , 012032,1-7. https://doi.org/10.1088/1755-1315/388/1/012032.

Al-Sultan, S.I., Sherief, M., Abdel-Raheem, Sherief, M.S., Abd-Allah, Abobakr, M. \& Edris., 2019. Alleviation of chronic heat stress in broilers by dietary supplementation of novel feed additive combinations. Slovenian Vet. Res. 56 (Suppl 22), 269-79. https://doi.org/10.26873/SVR-766-2019

Attia, Y.A., Bovera, F., Abd El-Hamid, A.E., Calabrò, S., Mandour, M.A., Al-Harthi, M.A. \& Hassan, S.S., 2019a. Evaluation of the carryover effect of antibiotic, bee pollen and propolis on growth performance, carcass traits and splenic and hepatic histology of growing rabbits. J. Anim. Physiol. Anim. Nutr. 103, 947-958. https://doi.org/10.1111/jpn.13068

Attia, Y.A., Bovera, F., Abd El-Hamid, A.E., Calabrò, S., Mandour, M.A., Nagdi, S.A., Mandour, M.A. \& Hassan, S.S., $2019 \mathrm{~b}$. Bee pollen and propolis as dietary supplements for rabbit: Effect on reproductive performance of does and on immunological response of does and their offspring. J. Anim. Physiol. Anim. Nutr. 103, 959-968. https://doi.org/10.1111/jpn.13069

Attia, Y.A., Bovera, F., El-Tahawy, W.S., El-Hanoun, A.M., Al-Harthi, M.A. \& Habiba, H.I., 2015. Productive and reproductive performance of rabbits does as affected by bee pollen and/or propolis, inulin and/or mannanoligosaccharides. World Rabbit Sci. 23, 273-282. https://doi.org/10.4995/wrs.2015.3644

Attia, Y.A., Abd Al-Hamid, A.E., Ibrahim, M.S., Al-Harthi, M.A., Bovera, F. \& El-Naggar, A.S., 2014. Productive performance, biochemical and hematological traits of broiler chickens supplemented with propolis, bee pollen, and mannan oligosaccharides continuously or intermittently. Livest. Sci. 164, 87-95. https://doi.org/10.1016/j.livsci.2014.03.005

Awadalla, S.A. \& Kamel, A.M., 2000. Effect of Nigella sativa seeds and oil on performance and some biochemical parameters in rabbit serum. Egypt. Vet. Nutr. J. 1, 31-42.

Bankova, V., 2005. Recent trends and important developments in propolis research. Evid. Based Complement. Alternat. Med. 2, 29-32. https://doi.org/10.1093/ecam/neh059

Biavatti, M.W., Bellaver, M.H., Volpato, L., Costa, C. \& Bellaver, C., 2003. Preliminary studies of alternative feed additives for broilers: Alternanthera brasiliana extract, propolis extract and linseed oil. Braz. J. Poult. Sci. 5(2), 1-6. https://doi.org/10.1590/S1516-635X2003000200009

Bronzwaer, S.L., Cars, O., Buchholz, U., Mölstad, S., Goettsch, W., Veldhuijzen, I.K., Kool, J.L., Sprenger, M.J.W. \& Degener, J.E., 2002. The relationship between antimicrobial use and antimicrobial resistance in Europe. Emerg. Infect. Dis. 8(3), 278-282. https://dx.doi.org/10.3201/eid0803.010192

Chegini, S., Kiani, A., Kavan, B.P. \& Rokni, H., 2018. Effects of propolis and stocking density on growth performance, nutrient digestibility, and immune system of heat-stressed broilers. Ital. J. Anim. Sci. https://doi.org/10.1080/1828051X.2018.1483750

Cimrin, T., Tunca, R.I., Avsaroglu, M.d., Ayasan, T. \& Küçükersan, S., 2020. Effects of an antibiotic and two phytogenic substances (cinnamaldehyde and 1,8-cineole) on yolk fatty acid profile and storage period-associated egg lipid peroxidation level. Rev. Bras. Zootec. 49, e20190270. https://dx.doi.org/10.37496/rbz4920190270

Daneshmand, A., Sadeghi, G.H. \& Karimi, A., 2012. The effects of a combination of garlic, oyster mushroom and propolis extract in comparison to antibiotic on growth performance, some blood parameters and nutrients digestibility of male broilers. Rev. Bras. Cienc. Avic. 14, 141-147. https://doi.org/10.1590/S1516-635X2012000200009

Daneshmand, A., Sadeghi, G.H., Karimi, A., Vaziry, A. \& Ibrahim, S.A., 2015. Evaluating complementary effects of ethanol extract of propolis with the probiotic on growth performance, immune response and serum metabolites in male broiler chickens. Livest. Sci. 178, 195-201. https://doi.org/10.1016/j.livsci.2015.04.012

Duarte, C.R.A., Eyng, C., Murakami, A.E. \& Santos, T.C., 2014. Intestinal morphology and activity of digestive enzymes in broilers fed crude propolis. Can. J. Anim. Sci. 94, 105-114. https://doi.org/10.4141/cjas2013-059 
Easton-Calabria, A., Demary, K.C. \& Oner, N.J., 2019. Beyond pollination: Honey bees (Apis mellifera) as zootherapy keystone species. Front. Ecol. Evol. 6, 161. https://doi.org/10.3389/fevo.2018.00161

Eyng, C., Murakami, A.E., Duarte, C.R. \& Santos, T.C., 2014. Effect of dietary supplementation with an ethanolic extract of propolis on broiler intestinal morphology and digestive enzyme activity. J. Anim. Physiol. Anim. Nutr. 98, 393401.

Eyng, C., Murakami, A.E., Duarte, C.R.A. \& Santos, T.C., 2013b. Effect of dietary supplementation with an ethanolic extract of propolis on broiler intestinal morphology and digestive enzyme activity. J. Anim. Physiol. Anim. Nutr. https://doi.org/10.1111/jpn.12116.

Eyng, C., Murakami, A.E., Pedroso, A.A., Duarte, C.R.A. \& Picoli, K.P., 2017. Caecal microbiota of chickens fed diets containing propolis. J. Anim. Physiol. Anim. Nutr. 101(3), 484-492

Eyng, C., Murakami, A.E., Pedroso, R.B., Silveira, T.G.V., Lourenço, D.A.L. \& Garcia, A.F.Q.M., 2013a. Crude propolis as an immunostimulating agent in broiler feed during the starter phase. Ciênc. Agrár. 34(5), 2511-2522. https://doi.org/10.5433/1679-0359.2013v34n5p2511

Eyng, C., Murakami, A.E., Santos, T.C., Silveira, T.G.V., Pedroso, R.B. \& Lourenço, D.A.L., 2015. Immune responses in broiler chicks fed propolis extraction residue-supplemented diets. Asian-Australas. J. Anim. Sci. 28(1), 135-142. http://dx.doi.org/10.5713/ajas.14.0066

FAO \& IFIF, 2010. Good practices for the feed industry-implementing the Codex Alimentarius code of practice on good animal feeding. Rome, Italy.

Gardana, C., Scaglianti, M., Pietta, P. \& Simonetti, P., 2007. Analysis of the polyphenolic fraction of propolis from different sources by liquid chromatography-tandem mass spectrometry. J. Pharm. Biomed. Anal. 45(3), 390-399.

Gheisari, A., Shahrvand, S. \& Landy, N., 2017. Effect of ethanolic extract of propolis as an alternative to antibiotics as a growth promoter on broiler performance, serum biochemistry, and immune responses. Vet. World 10(2), 249-254. www.veterinaryworld.org/Vol.10/February-2017/18.pdf

Hanhineva, K., Törrönen, R., Bondia-Pons, I., Pekkinen, J., Kolehmainen, M., Mykk€anen, H. \& Poutanen, K., 2010. Impact of dietary polyphenols on carbohydrate metabolism. Intl. J. Mol. Sci. 11, 1365-1402. https://doi.org/10.3390/ijms11041365

Haščik, P., Pavelkova, A., Arpasova, H., Cubon, J., Kacaniova, M. \& Kunová, S., 2019. The effect of bee products and probiotic on meat performance of broiler chickens. J. Microb. Biotech. Food Sci. 9(1), 88-92.

Haščík, P., Trembecká, L., Bobko, M., Kačániová, M., Čuboň, J., Kunová, S. \& Bučko, O., 2016. Effect of diet supplemented with propolis extract and probiotic additives on performance, carcass characteristics and meat composition of broiler chickens. Potravinárstvo 10(1), 223-231. https://doi.org/10.5219/581

Hassan, R.I.M., Mosaad, G.M.M. \& Abd El-Wahab, H.Y., 2018. Effect of feeding propolis on growth performance of broilers. J. Adv. Vet. Res. 8(3), 66-72.

Hosseini, S.M., Azghandi, V.M., Ahani, S. \& Nourmohammadi, R., 2016. Effect of bee pollen and propolis (bee glue) on growth performance and biomarkers of heat stress in broiler chickens reared under high ambient temperature. J. Anim. Feed Sci., 25, 45-51. https://doi.org/10.22358/jafs/65586/2016

Khafaji, S.S.O., Aljanabi, T.K. \& Suhailaltaie, S.M., 2019. Evaluation the impact of different levels of propolis on some reproductive features in Iraqi local roosters. Adv. Anim. Vet. Sci. $7(2)$, 82-87. http://dx.doi.org/10.17582/journal.aavs/2019/7.2.82.87

Khan, S.H., 2017. Recent advances in role of propolis as natural additive in poultry nutrition. J. Apic. Sci. 61(2), 167-183. https://doi.org/10.1515/jas-2017-0020

Khattak, F.M., Pasha, T.N., Hayat, Z. \& Mahmud, A., 2006. Enzymes in poultry nutrition. J. Anim. Plant Sci. 16(1-2), 1-7.

Khodanazary, A., Tatar, A. \& Khezri, M., 2011. Effects of different dietary levels of propolis on performance, carcass characteristics and immunity response of broiler chickens. J. Ethnopharm. 2, 80-83.

Kinasih, I., Julita, U., Suryani, Y., Cahyanto, T., Annisa, D.S., Yuliawati, A. \& Putra, R.E., 2018. Addition of black soldier fly larvae (Hermetia illucens L.) and propolis to broiler chicken performance. IOP Conference Series: Earth Environ. Sci. (187), 012026. http://dx.doi.org/10.1088/1755-1315/187/1/012026.

Klarić, I., 2014. Production and health effects of propolis and bee pollen as food additives in broilers feeding. Poljoprivreda 20 (2), 61-64.

Klarić, I., Domaćinović, M., Šerić, V., Miškulin, I., Pavić, M. \& Paradinović, K., 2015. Effects of bee pollen and propolis on performance, mortality, and some haematological blood parameters in broiler chickens. Slovak Vet. Res. 55(1), 23-34. DOI: 10.26873/svr-385- 2018

Klarić, I., Pavic, M., Miskulin, I., Blazicevic, V., Dumic, A. \& Miskulin, M., 2018. Influence of dietary supplementation of propolis and bee pollen on liver pathology in broiler chickens. Animals 8, 54. https://doi.org/10.3390/ani8040054.

Krocko, M., Canigova, M., Bezekova, J., Lavova, M., Hascik, P. \& Duckova, V., 2012. Effect of nutrition with propolis and bee pollen supplements on bacteria colonization pattern in gastrointestinal tract of broiler chickens. Sci. Pap. Anim. Sci. Biotechnol. 45, 63-67.

Liu, G., Yan, W. \& Zeng, Z., 2010. Application of bee pollen on the Gallus feed. Bee J. 3, 22-29.

Lotfy, M., 2006. Biological activity of bee propolis in health and disease: Review. Asian Pac. J. Can. Prev., 7, 22-31

Mahmoud, M.A.M., Abdel-Mohsein, H.S. \& Mahmoud, U.T., 2013. Effect of Chinese propolis supplementation on Ross broiler chicks: Microbial population in fecal matter and litter. J. Adv. Vet. Res. 4(2), 77-84.

Mahmoud, U.T., Amen, O.A., Applegate, T.J. \& Cheng, H.W., 2017. Brazilian propolis effects on growth, productivity performance, gut characteristics and physiological changes in broiler chickens. Intl. J. Poult. Sci. 16(5), 169-179. https://doi.org/10.3923/ijps.2017.169.179

Marcucci. M.C., 1995. Propolis: chemical composition, biological properties and therapeutic activity. Apidologie 26, 8399. DOI: $10.1051 /$ apido:19950202 
Mishima, S., Inoh, Y., Narita, Y., Ohta, S., Sakamoto, T., Araki, Y., Suzuki, K.M., Akao, Y. \& Nozawa, Y., 2005. Identification of caffeoylquinic acid derivatives from Brazilian propolis as constituents involved in induction of $\mathrm{HL}$ 60 cells. Bioorg. Med. Chem. 13, 5814-5818. https://doi.org/10.1016/j.bmc.2005.05.044.

Nir, I., Ve-Senkoylu, N., 2000. Supporter feed additive for poultry digestive. Roche Ltd., UK.

Omar, A.J., Hejazi, A. \& Badran, R., 2016. Performance of broilers supplemented with natural herb extract. Open J. Anim. Sci. 06(1), 68-74. http://dx.doi.org/10.4236/ojas.2016.61009

Page, M.J., Moher, D., Bossuyt, P.M., Boutron, I., Hoffmann, T.C., Mulrow, C.D. Shamseer, L., Tetzlaff, J.M., Akl, E.A Brennan, S.E., Chou, R., Glanville, J., Grimshaw, J.M., Hróbjartsson, A., Lalu, M.M., Li, T., Loder, E.W., MayoWilson, E., McDonald, S., McGuinness, L.A., Stewart, L.A., Thomas, J., Tricco, A.C., Welch, V.A., Whiting, P. \& McKenzie, J.E., 2021. PRISMA 2020 explanation and elaboration: updated guidance and exemplars for reporting systematic reviews BMJ 372, 160. DOI: 10.1136/bmj.n160

Park, Y.K., Alencar, S.M. \& Aguiar, C.L., 2002. Botanical origin and chemical composition of Brazilian propolis. J. Agric. Food Chem. 50(9), 2502-2506. https://doi.org/10.1021/jf011432b.

Pascoal, A., Rodrigues, S., Teixeira, A., Feas, X. \& Estevinho, L.M., 2014. Biological activities of commercial bee pollens: Antimicrobial, antimutagenic, antioxidant and anti-inflammatory. Food Chem. Toxic. 63, 233-239. http://dx.doi.org/10.1016/j.fct.2013.11.010.

Pinheiro, J., Bates, D., Debroy, S., Sarkar, D. \& R Core Team., 2020. nlme: Linear and nonlinear mixed effects models. R package version 3.1-150, https://CRAN.R-project.org/package=nlme

Prakatur, I., Miskulin, M., Pavic, M., Marjanovic, K., Blazicevic, V., Miskulin, I. \& Domacinovic, M., 2019. Intestinal morphology in broiler chickens supplemented with propolis and bee pollen. Animals (9)301, 1-12. https://doi.org/10.3390/ani9060301

PubMed, 2021. https://www.ncbi.nlm.nih.gov/pmc/ National Center for Biotechnology Information, U.S. National Library of Medicine, Bethesda, Maryland, USA

R Core Team., 2020. R: A language and environment for statistical computing. Vol. 2. Vienna, AT: R Core Team.

Rabie, A.H., El-Kaiaty, A.M., Hassan, M.S.H. \& Stino, F.K.R., 2018. Influence of some honeybee products and a growth promoter supplementation on productive and physiological performance of broiler chickens. Egypt. Poult. Sci. J. 38(II), 513-531.

Sahin, H.A. \& Ozturk, E., 2018. Effects of raw propolis or water and ethanol extracts of propolis on performance, immune system, and some blood parameters of broiler breeders. Rev. Bras. de Zootec. 47, e20170161. https://doi.org/10.1590/rbz4720170161

Sauvant, D., Schmidely, P., Daudin, J.J. \& St-Pierre, N.R., 2008. Meta-analyses of experimental data in animal nutrition. Animal 2(8), 1203-1214. https://doi.org/10.1017/S1751731108002280

Science Direct, 2021. https://www.sciencedirect.com/ Elsevier, Amsterdam, Netherlands.

Scopus, 2021. https://www.scopus.com/ Elsevier, Amsterdam, Netherlands.

Seven, I., Aksu, T. \& Seven, P.T., 2010. The effects of propolis on biochemical parameters and activity of antioxidant enzymes in broilers exposed to lead-induced oxidative stress. Asian-Australas. J. Anim. Sci. 23(11), 1482-1489. https://doi.org/10.5713/ajas.2010.10009

Seven, P.T., 2008. The effect of dietary Turkish propolis and vitamin C on performance, digestibility, egg production and egg quality in laying hens under different environmental temperatures. Asian-Australas. J. Anim. Sci. 21(8), 1164117. https://doi.org/10.5713/ajas.2008.70605.

Seven, P.T. \& Seven, I., 2008. Effect of dietary Turkish propolis as alternative to antibiotic on performance and digestibility in broilers exposed to heat stress. J. Appl. Anim. Res. 34(2), 193-6. https://doi.org/10.1080/09712119.2008.9706970

Seven, P.T., Seven, I., Yilmaz, M. \& Simsek, U.G., 2008. The effects of Turkish propolis on growth and carcass characteristics in broilers under heat stress. Anim. Feed Sci. Technol. 146(1-2), 137-148. http://dx.doi.org/10.1016/j.anifeedsci.2007.11.003.

Seven, P.T., Yilmaz, S., Seven, I. \& Kelestemur, G.T., 2012. The effects of propolis in animals exposed oxidative stress. Intechopen 267-288. https://doi.org/10.5772/34850.

Shaddel-Tili, A., Eshratkhah, B., Kouzehgari, H. \& Ghasemi-Sadabadi, M., 2017. The effect of different levels of propolis in diets on performance, gastrointestinal morphology and some blood parameters in broiler chickens. Bulgarian $\mathrm{J}$. Vet. Med. 20(3), 215-224. https://doi.org/10.15547/bjvm.986

Shalmany, S.K. \& Shivazad, M., 2006. The effect of diet propolis supplementation on Ross broiler chicks performance. Int. J. Poult. Sci. 5(1), 84-88. http://dx.doi.org/10.3923/ijps.2006.84.88.

St-Pierre, N.R., 2001. Invited Review: Integrating quantitative findings from multiple studies using mixed model methodology. J. Dairy Sci. 84(4), 741-55. https://doi.org/10.3168/jds.S0022-0302(01)74530-4.

Taheri, H.R., Rahmani, H.R. \& Pourreza, J., 2005. Humoral immunity of broilers is affected by oil extracted propolis (OEP) in the diet. Intl. J. Poult. Sci. 4(6), 414-417.

Tekeli, A., Kutlu, H.R. \& Celik, L., 2011. Effect of Z. officinale and propolis extracts on the performance, carcass, and some blood parameters of broiler chicks. Cur. Res. Poult. Sci. 1(1), 12-23. https://doi.org/10.3923/crpsaj.2011.12.23.

Toghyani, M., Toghyani, M. \& Tabeidian, S.A., 2011. Effect of probiotic and prebiotic as antibiotic growth promoter substitutions on productive and carcass traits of broiler chicks.2011 International Conference on Food Engineering and Biotechnology, Singapore.

Torki, M., Soltani, J. \& Mohammadi, H., 2015. Effects of adding ethanol extract of propolis and cumin essential oil to diet on the performance, blood parameters, immune response and carcass traits of broiler chicks. Iran J. Appl. Anim. Sci. 5(4), 911-918. http://ijas.iaurasht.ac.ir/article_516543.html 
Wang, J., LI, S., Wang, Q., Xin, B. \& Wang, H., 2007. Trophic effect of bee pollen on small intestine in broiler chickens. J. Med. Food. 10: 276-280. https://doi.org/10.1089/jmf.2006.215

Yamaguchi, M., Hamamoto, R., Uchiyama, S., Ischiyama, K. \& Hashimito, K., 2006. Anabolic effects of bee pollen Cistus ladaniferus extract on bone components in the femoral-diaphyseal and-metaphyseal tissues of rats in vitro and in vivo. J. Health Sci. 52(1), 43-49. https://doi.org/10.1248/jhs.52.43.

Ziaran, H.R., Rahmani, H.R. \& Pourreza, J., 2005. Effect of dietary oil extract of propolis on immune response and broiler performance. Pak. J. Biol. Sci. 8(10), 1485-1490. https://doi.org/10.3923/pjbs.2005.1485.1490. 